\title{
The Constitutionality of the Jordanian Prevention of Crimes Act No. 7 For the year 1954
}

\author{
Dr. Ahmed Refaie \\ Associate Professor \\ Faculty of Law \\ Applied Science Private University \\ Jordan
}

\begin{abstract}
One of the most significant constitutional principles is the separation of powers. This principle is one of the most important elements of the legal state which means that the Constitution determines the powers of each authority and that these powers cannot be infringed by another authority. Given the wide range and scope of the state activity, where the responsibilities of the governor increased after the state was a guard of public security and public safety, and turned into an interventionist state and then a productive state. Therefore, powers and competences had to be distributed across the authorities within the State, and this separation of powers must not be an absolute separation, but rather the flexibility that would allow for cooperation between the authorities. By examining the Prevention of Crimes Act, the researcher found that it contains many articles which violates the Separation of Powers Principle, where it was noted that there is an infringement of the administrative governors on powers and competences of the judiciary. Therefore, the executive authority should not apply this Act and not be dragged behind the legislature in violation of the Constitution. This study sheds the light on the constitutionality of this law and concludes with some recommendations.
\end{abstract}

Keywords: Constitutionality of laws, The Principle of Constitutional Supremacy, Administrative Governor, Prevention of Crimes Act, Administrative Detention, Administrative Arrest, Release on Bail, House Arrest, presence under conditions of suspicion, Police, Judicial Officer.

\section{Introduction:}

It is a well recognized principle in democratic systems that the Constitution is the source of all powers, which governs the fundamental powers of the State, determines the relationship between them and defines the rights and duties of individuals. In this regard, scholars agreed upon adopting the Separation of Powers Principle which requires that every authority be independent in the exercise of the function assigned to it by the Constitution, so that no authority may exceed the function of another authority entailing that the legislature may not go beyond the functions of legislation and control over governmental performance unless there are constitutional provisions allowing it to do so. The function of the executive authority is limited to making public or individual decisions, so that it may not engage in judicial or legislative work except in exceptional cases and on the basis of a constitutional provision. The same applies to the judiciary, whose function must be limited to the application of the law to disputes brought before it, whether such disputes occur between individuals as a result of the clash between their rights and freedoms or between public authorities and individuals when the executive authority exercises its functions and the infringement of the rights and freedoms of individuals.

However, it is not enough to reflect in the Constitution on the organization of the basic powers of the state, the determination of the relationship between them and the identification of the rights and duties of individuals. Hence, there must also be safeguards to ensure that the powers created by the Constitution respect the jurisdictions entrusted to them so that they do not exceed them which can be achieved through control over the acts of these authorities and the consequent sanctions that would nullify the defective act, whether directly or indirectly, and this is called the principle of the Constitutionality of Laws.

The researcher believes that there is a similarity in the unconstitutionality of Prevention of Crimes Act No. 7 for the year of 1954, as it contradicts the principle of civil liberties and civil rights and is contrary to the principles of democracy and the rule of law, especially since it gives to the administrative governor absolute powers to restrict the freedoms by imprisonment, arrest and association with a pledge or bail. This leads us to say that this law is not compatible with the principles of the Jordanian Constitution or to the Universal Declaration of Human Rights.

This research has been divided as follows:

1) The Principle of Constitutional Supremacy and Control of the Constitutionality of laws.

1.1. The Principle of Constitutional Supremacy and its types. 
1.2. Types of Control over the Constitutionality of Laws.

2) Introducing the Prevention of Crime Act and the powers of Administrative Governors.

2.1. Introducing the Prevention of Crime Act.

2.2. The Law of Prevention of Crimes and the encroachment upon the competences of the Judicial Authority.

Thereafter, a summary of the research along with some recommendations will be presented by the researcher who hopes that this research will achieve a great success.

\section{The Principle of Constitutional Supremacy and Control of the Constitutionality of Laws.}

Scholars and politicians both recognize the Principle of Constitutional Supremacy. Rather, some Constitutions have expressly decided to conclude that principle in their Constitutions, such as Arizona, Dakota and Washington in the United States ${ }^{1}$. Also, it was stipulated in Article 1, paragraph 2 of the Czechoslovakian Constitution in 1920 that "public authorities in the state are subject to the constitution and abide by its provisions" and the Italian Constitution in 1947, which stated the Constitutional Supremacy over the public agencies in the state ${ }^{2}$.

The merit of the Constitution is that it's the bedrock upon which a state and it's legal system are built, it is the source of every legal activity within the state. Therefore, it must be the supreme legal force of all forms of that legal activity and binding on all public agencies in the state since the constitution established and developed these agencies and determined their competencies.

The constitution is the general framework of all forms of legal activity in the state and any action or activity which violates the objectives and directions set by the constitution shall be void.

Therefore, the supremacy of the constitutions must be maintained. This research will tackle the meaning of constitutional supremacy and its types and will address control of constitutional laws and its types.

\subsection{Constitutional Supremacy and its types.}

As mentioned earlier, the Supremacy of Constitutions, both customary and written, is meant to be considered the supreme legal force in the state and this prevails only in democratic systems and fails in dictatorial regimes where governors do not recognize the constitution or other laws ${ }^{3}$.

The Supremacy of Constitutions is a recognized principle in the constitutional doctrine even if not provided in the constitutions. However, some constitutions stipulated the constitutional supremacy such as the Constitution of the Soviet Union of 1977, which stipulates in Article 173 that "The Constitution of the USSR shall have supreme legal force. All laws and other acts of state bodies shall be promulgated on the basis of and in conformity with it.".

Such a provision was also stipulated in the Italian Constitution of 1947 and the Constitution of the Republic of Somalia of $1960^{4}$. The reason behind the Constitutional Supremacy is that it contains substantive rules and provisions which are considered to be the basic law by which the legal system in the state is determined. The Constitution determines state authorities and the powers of these authorities which these authorities shall respect and abide to it - this is called Material Supremacy - taking into consideration the subject and content of the Constitutional provisions and this applies in customary, written, flexible and rigid constitutions 5 .

The supremacy of constitutions may lie in the rules that define the methods or procedures of its development or amendment, which is called Formal Supremacy and is achieved only for rigid written constitutions. We will discuss each type of supremacy as follows:

\section{First: Material Supremacy}

As we mentioned earlier, the constitution is the fundamental source which governs the legal system in a state, it determines the powers of the governing bodies and their activities which must adhere to the constitution otherwise they will be null and void. There are two forms of Material Supremacy:

1. The constitution is the legitimate grounds of the governing bodies existence in the state. It determines the powers of these authorities which are not granted to them as their own right, but as functions must be exercised on behalf of the state. Since it is the constitution which establishes these authorities and determines their competencies and activities, these authorities must subject to the provisions of the constitution.

\footnotetext{
${ }^{1}$ Al Badawi. Tharwat (1971), Constitutional Law and Constitutional Development in Egypt, Dar Al Nahda, Cairo, p.930.

${ }^{2}$ Go Burdeau, Traite De Science politique, t. III, n.82.

${ }^{3}$ Shiha. Abedl Aziz (1982), The General Principles of The Constitutional Law, Al Dar Al-Jame'a, Cairo, p.175.

${ }^{4}$ Al Khatib. Nu'man (2017), Mediator in Political Systems and Constitutional Law, Dar Al Thaqafa, Amman, p.473.

${ }^{5}$ Al Badawi. Tharwat,(A revision of Abedl Aziz Shiha's book, p.175).

112
} 
2. The constitution is what determines the law prevailing in the state and determines the philosophy underlying the applicable legal regime, politically, socially or economically. These governing agencies must respect constitutional provisions and abide by the constitution when exercising their activities.

The consequences of Material Supremacy are:

1. Upholding the Principle of Legitimacy in the eyes of individuals and expanding its scope to cover the constitutional provisions as well as the ordinary rules and laws and therefore all state authorities must respect the constitutional provisions and it is important to apply the Principle of Legitimacy on decisions contrary to the constitution regardless of who made them.

2. The Material Supremacy prevents the possibility of delegating competencies, as it is the constitution which delegates competencies to the authorities and the public agencies which can not be delegated again. The secret of establishing this principle is that the constitution mandates competencies of authorities taking into consideration the safeguards of the means and methods followed while choosing a governor. Therefore, no governing body in the State may authorize or delegate others to exercise its constitutional competencies unless the Constitution stipulates otherwise and explicitly authorizes the authorization ${ }^{6}$.

\section{Second: Formal Supremacy}

As is well known, protecting the supremacy of the constitution inevitably means protecting the rules, rights and freedoms of individuals that the constitution include and we have seen that Material Supremacy is based on constitutional subjects in substantive terms. This importance is of a political nature and the supremacy of a legal character which has implications in the legal sphere, is based on the form and procedures by which the Constitution is established or required to amend it. This supremacy can only be achieved if the constitution is rigid, because this inflexibility is what gives the constitutional rules a special and supreme status among various legal rules. Therefore, the basis of Material Supremacy lies in the fact that the constitutional rules occupy the highest position in the hierarchy of the state's legal system.

All individuals and authorities must adhere and abide to the constitution. Hence, the legislature must respect the constitution and abide by its legislations. Judicial authorities should also respect the constitution and apply its provisions if it was brought up in a case before the judicial court. The executive authority should also abide to the constitution in their actions. Otherwise, administrative actions contrary to the Constitution are considered illegal and must be abolished and compensated for ${ }^{7}$.

The formal supremacy of the constitutions stipulates that the Constitution can only be amended by a constitutional provision with an equally binding provision. No ordinary law may amend the Constitution, and the legislature may not enact a constitution because that is a constitutional power, and that the constitution established these authorities and determined their competencies. Therefore, how can the creature create the Creator!

The formal supremacy of constitutions also means that constitutional rules are fixed, because rigid constitutions cannot be changed in the same manner as ordinary laws. constitutions are more firm and stable than ordinary rules, therefore amending it can be a difficult process ${ }^{8}$.

Hence, we can distinguish between constitutional laws and ordinary laws, and this is the basis or standard for the Formal Supremacy of the Constitution. constitutional provisions differ from the provisions of ordinary laws in terms of subject matter, where constitutional laws examine the form of regime, the form of government, the form of the state, the government, the governing bodies and those relating to public rights and freedoms, while ordinary laws does not include such matters ${ }^{9}$. In addition, constitutional rules and legal rules differ in terms of who is establishing these rules or in terms of their amendment procedures.

Accordingly, the right way to protect the formal supremacy of constitutions is through control over the constitutionality of laws ${ }^{10}$.

\subsection{Types of Control over the Constitutionality of Laws.}

The subject of Control over the constitutionality of laws is an example of a legal state, which means that governors and the governed are subject to the law and that governors subjection means that all state authorities are subject to the law in general and the Constitution as the supreme legal force in the state.

\footnotetext{
${ }^{6}$ Abdel-Aal , Mohammad Hassanein, ibid(taken from Ibrahim Shiha's book, p. 179), p. 108

${ }^{7}$ Al Badawi. Tharwat (1971), Constitutional Law, Dar Al Nahda, Cairo, p.98.

${ }^{8}$ Khalil. Muhsin (1997), Constitutional Law of United Arab Emirates, Cairo, p.25.

${ }^{9}$ Ali Eldibs. Issam (2011), Constitutional Law, Dar Al Thaqafa, Amman, p.172.

${ }^{10}$ Karam. Ghazi (2009), Political Systems and Constitutional Law, Sharjah University Library, Sharjah, p.270

113
} 
If the Constitution is the most supreme legal force in the state, its supremacy turns into inutility if the state authorities and bodies can violate it without imposing sanctions against such a violation ${ }^{11}$. There must be safeguards to ensure that these public authorities respect the provisions of the Constitution, as it determined the competencies of these authorities within the limits of their competence.

Actions and acts of the Executive Authority must be in conformity with the provisions of the constitution. Otherwise, they will be considered illegal and must be abolished. Ensuring that the constitution is respected by the Executive authority is safeguarded by the judiciary with its right of control the legality of actions of these authorities.

As for the legislative authority, the principle of constitutional supremacy, the consequent hierarchy of legal rules in the state and the supreme status of the Constitution among these rules forces the legislative authority to respect the provisions of the Constitution, where it is not permissible to issue legislation contrary to the Constitution or even the spirit of the Constitution ${ }^{12}$. Otherwise, the legislative authority would be considered to be beyond the limits of its competencies and the legislations produced by this authority would be unconstitutional and must be abolished. This nullity may be stipulated in the constitutions within their texts, however, the lack of providing a legal text on this nullity does not affect the nullity of the laws issued in contrary with the provisions of the Constitutions, as nullity is an inevitable result without the need to be expressly stated.

The question of whether or not the Ordinary Law is compatible with provisions of the Constitution, is what can be called the Constitutionality of Laws.

Before presenting types of control over the constitutionality of laws, two important things must be noted:

1. The constitutionality of laws is raised only in a rigid constitution, where it requires special procedures that are far more complex than those used to amend ordinary laws. on the other hand, the constitutionality of laws could never be raised in a flexible constitution, as is the case in Britain ${ }^{13}$.

2. The constitutionality of laws is raised only when the law is incompatible with the provisions of the constitution in terms of the subject matter, because control over the constitutionality of laws depend on the conformity of the law with the constitution from a substantive aspect and while disregarding the formal aspect. If the law is passed in contrary with the Constitution, then it can not be considered legal and is non-existent and the judiciary has the right to refrain from applying it, and this rule is recognized by jurisprudence and justice14. Control over the constitutionality of laws and the extent to which they conform to the provisions of the Constitution is raised only when these laws have been issued with the formalities and procedures stipulated and included in the Constitution.

We will examine each of these methods:

\section{First: Political Control}

This type of control can only be used according to a provision stipulated by the Constitution. This type is used to control draft laws, i.e. before they become laws issued by the head of state and assigned to a political body. It is a preventive control method because it precedes the promulgation of laws, assuming that there is a body established by the Constitution whose task is to verify that acts of the legislature are in conformity with the provisions of the Constitution. the French Constitution of October 1958 is one of the constitutions that adopted political control which was assigned to a political body called the Constitutional Council. This council consists of two types of members appointed by law. The first type is the former Presidents of the Republic whose membership is for life, while the second type consists of nine selected members three appointed by the President of the Republic, three appointed by the President of the National Assembly and three appointed by the President of the Senate. The term of office of these nine members is a non-renewable term of nine years, knowing that every three years, one third of the seats falls vacant, and that the president of the council is appointed by the President of the Republic ${ }^{15}$.

The Constitutional Council is competent to examine whether or not the draft laws comply to the Constitution.

It may be argued that it is logical to give the task of controlling the constitutionality of laws to a political body for two reasons; the first reason is that preventive control prevents the promulgation of a law contrary to the Constitution and therefore is more effective than other forms of control, i.e. after the promulgation of the law in accordance with the principle of prevention is better than cure. The second reason is that political control is more consistent with the nature of the implications of regulating the constitutionality of laws. The authority entrusted with verifying the constitutionality of laws will gain a high status for other established authorities, including the legislative authority, where activities of these public authorities will be subject to the control of that entrusted authority.

\footnotetext{
${ }^{11}$ George Burdeau Op. 95 Claude Lecleraq . Op. eit p.90.

${ }^{12}$ AndreHauriou . Op.eit p. 340.

${ }^{13}$ Helmi. Mahmoud, Constitutional Law and Political Systems, p.95.

${ }_{15}^{14}$ Al Attar. Fuad, p.248.

${ }^{15}$ The French Constitution for the year of 1958 .

114
} 
Therefore, the entrusted authority can obstruct activities of such authorities, determine their competencies and prevent the effectiveness of their actions whenever they are found to be contrary to the provisions of the Constitution. Hence, the task of controlling the constitutionality of laws is of a political nature taking into consideration the consequences of this process, and it is logical to place this task in the hands of a political body ${ }^{16}$.

However, this type of control was criticized in the following manner:

1. The Control over the constitutionality of laws is of an undeniable legal nature, which should be taken into account when forming a control body, as it requires technical qualifications and legal competencies ${ }^{17}$.

If so, it is makes no sense to give the task of controlling the constitutionality of laws to a political body, whose members are able to understand the law and the problems that arises, as this body will prevail political considerations over legal considerations ${ }^{18}$.

2. Control over the constitutionality of laws means putting an end to the political tendencies and whims of the legislative authority and preventing its tyranny if left uncontrolled. Therefore, the adoption of political control constitutes a great and indisputable risk because the political body entrusted with the task of controlling the constitutionality of laws can be subject to the same political tendencies and whims to which the legislative authority is subject to.

3. It has also been said in criticisms of political control that politicians are chosen in one way or another which makes them subordinate to other authorities in the state, and therefore the standards of independence and freedom required for the establishment of the body which will control the constitutionality of laws will be lost.

4. Political control will prevent individuals from challenging the constitutionality of laws after the promulgation of the law, as well as preventing them from determining the entities that may recourse to the political body ${ }^{19}$.

These are the criticisms of political control that led to the shrinkage and atrophy of this method and resort to judicial control.

\section{Second: Judicial Control}

This means that the task of examining laws to verify compliance with the provisions of the Constitution should be assigned to a judicial body, i.e. a post control of the promulgation of laws. Since this field is an area of competence of the jurisdiction, it is by nature, a core judicial function. Therefore, when the judiciary controls the constitutionality of laws, that does not constitute an infringement of the competencies of the legislative authority, for there is differences between two contradicting texts in the case presented before it, one constitutional and the other an ordinary legislation, where the constitutional text is applied and the legislative one is excluded. only In the absence of a constitutional provision which determines the competent judiciary to control the constitutionality of laws, we are left with the socalled control of abstinence. However, if the matter is resolved and the constitution determines a judicial body competent to control the constitutionality of laws, then we are not violating the principle of separation of powers and this body is competent to repeal the law contrary to the Constitution.

Control of abstinence and control of cancellation:

\section{Control of Abstinence;}

Constitutions of some states were not established by the body responsible for controlling the constitutionality of laws, resulting in the need to perform due diligence which led to the recognition of this jurisdiction in all courts of the state ${ }^{20}$. This type was adopted in the United States of America by federal and local courts. The failure of the legislator to determine a body that controls the constitutionality of laws means that control of the constitutionality of laws cannot be determined by an original lawsuit requesting the repeal of the law, but that does not prevent the search for another judicial means to impose any type of control over the constitutionality of laws.

However, entrusting the judiciary through subject judgment with adjudicating disputes and applying its provisions to such disputes enforces the judiciary to interpret the law, to state which provision applies in the cases presented before it. If it is found that there is a conflict between one law and another, the judge must act upon a well-known rules of interpretation and that the newest law shall be supersede the oldest law. He should also prevail the supreme law in the hierarchy of the state's legal system, operationalize the Constitutional provision and neglect the Ordinary Law when there is a violation of the constitution.

\footnotetext{
${ }_{17}^{16}$ Al Badawi. Tharwat (1971), Constitutional Law and Constitutional Development in Egypt, Dar Al Nahda, Cairo, p.122.

${ }^{17}$ Al Sha'er. Ramzi Taha, ibid p.253.

${ }^{18} \mathrm{Al} \mathrm{Baz}$

Saed Ali, p.107.

${ }^{19}$ Al Jurof. Taima, p.146.

${ }^{20}$ Rebat. Edmone (1971) Mediator in General Constitutional Law, $2^{\text {nd }}$ ed., Dar El Ilm Lilmalayin, Beirut, p.532.

115
} 
Therefore, a constitutional provision is not necessary to organize control over the constitutionality of laws and if the constitution remained silent, subject judgment of the unconstitutionality of laws is the only way to be used in an original case, as it doesn't request the repeal of the law, i.e. doesn't take an offensive form as a constitutional case throughout the original direct case.

For example, a university student should file an application to overturn an administrative decision that was issued to dismiss him disciplinarily before the competent judicial authority, against the university that issued the dismissal decision, and then argue during the proceedings that the university law is unconstitutional.

Based on the foregoing, we can say that abstinence control derives its legitimacy from the nature of the work of the judge and the need to adhere to the oath he swore to preserve the Constitution and not be dragged behind the legislature by the application of unconstitutional law.

\section{Control of Cancellation}

Control of Cancellation means that the concerned party affected by a particular law must challenge this law directly and without having to wait for the law to be applied to it. He can demand the repeal of this law by the competent court, which can repeal this law if found to be unconstitutional and applies to all and retroactively or for the future only as determined by the constitutional provisions.

In the view of the seriousness of this type of control and its decisive and conclusive outcomes, it would seem unreasonable to leave this authority under the control of ordinary courts as in Control of Abstinence. Hence, it is reasonable to entrust one court with this type of control i.e. control centralization. This can be applied through the following methods:

The first method is to make control over the constitutionality of laws of the task of the Supreme Court in the ordinary judicial system ${ }^{21}$, where this court can deliver a binding judgment and the supreme court's ruling has an absolute argument. Therefore, the rendered judgment on the unconstitutionality of challenged law shall be abolitionist and some constitutions stipulate that unconstitutional judgments should be published in the same way as laws.

The second method is to make this type of control part of the jurisdiction of a specialized constitutional court established to this end. The Jordanian Constitution is one of the constitutions that adopted this form as it is stipulated in Article 58 of it that "A Constitutional Court shall be established - by a law - the headquarters of which shall be in the Capital; shall be considered as an independent and separate judicial body...". Article 59 also stipulates that "The Constitutional Court shall have the competence of oversight on the constitutionality of the applicable laws and regulations and its judgments shall be issued in the name of the King; its judgments shall be final and binding on all authorities and on all; its judgments shall as well be effective immediately unless the judgment specifies another date for its effectiveness; the judgments of the Constitutional Court shall be published in the Official Gazette within fifteen days of the date of their issuance ${ }^{22}$, and the Constitutional Court shall have the right to interpret the provisions of the Constitution if such is requested therefrom".

The constitutions determine the parties that may challenge the unconstitutionality of the laws of the Jordanian Constitution and that there are two ways to appeal before the Constitutional Court the direct way is through the Senate, the House of Representatives and The Council of Ministers.

The indirect way is through the case viewed by courts, any of the parties of the case may raise the issue of the nonconstitutionality; the court shall - if it finds that the plea is serious - refer it to the court specified by the law for the purposes of the determination of its referral to the Constitutional Court.

In the second section, we will discuss the Crime Prevention Act in Jordan and its compatibility with the Constitution.

\section{Introducing Crime Prevention Act and the attack on the competencies of the Judicial Authority.}

It is well known that any law enacted by the legislature must be compatible not only with the constitutional texts but also with the spirit of the Constitution. The Jordanian Constitution stipulates the principle of separation of powers, which means that every authority shall abide by the competencies identified by the Constitution.

The Jordanian constitution stipulated that "The Legislative Power shall be vested in the National Assembly and the King. The National Assembly shall consist of a Senate and a Chamber of Deputies. The Executive Power shall be vested in the King, who shall exercise his powers through his Ministers in accordance with the provisions of the present Constitution".

\footnotetext{
${ }^{21}$ Khalil. Othman (1974), Modern Constitutional Trends, Dar Al Nahda, Cairo, p.93.

${ }^{22}$ Jordanian Constitution For the year of 1952.

116
} 
The judicial authority shall be vested in all courts of all kinds and degrees, and that all judicial decisions are issued in accordance with the law in the name of the King.

Based on the forgoing, no authority may exceed the function of another authority and the legislative authority may not enact a law whereby an authority is permitted to exercise the function of another authority.

Later on this research, we will examine the nature of the Crime Prevention Law and its relationship with the Criminal law presented earlier, and then we will present forms of abuse of the executive authority on the jurisdiction of the Judicial authority under the Crime Prevention Law.

\subsection{Introducing Crime Prevention Act:}

There is no doubt that the law and any law is the legislator's response to the reaction of society. Therefore, when the legislative authority enacts a law, it must take into account the interests of society, the interest of society in that no innocent person shall be convicted and that no criminal escapes punishment. This legal principle is matched by another legal principle, which is that 60 criminals can escape punishment but no innocent should be convicted. Another constitutional principle stipulates that "No person may be prosecuted more than once for one and the same offense and that The accused is innocent until proven guilty". Therefore, the State must take preventative and precautionary measures to prevent crime and its spread within the society. The tasks of administrative governors is important and tangible, and everyone may disagree on the Crime Prevention Law, which allows administrative governors to overrun individual freedoms, although we feel it is a great proposal if applied to those criminals who have committed crimes and excelled in circumventing the laws. Governors also are sometimes responsible for long prosecutions in clear and visible cases where the offense is visible.

On the other hand, the implementation of the law is subject in all cases to the administrator's situational assessment which varies from person to person. Some administrators depend on the received police reports.... many cases were sent to administrative rulers because of their presence in suspicious circumstances stipulated in the Prevention of Crimes Law, which abuses and violates the freedoms protected by all constitutions.

Based on the foregoing, the Jordanian Prevention of Crimes Act No. 7 for the year of 1954 is the law which grants the administrative rulers the powers, competencies and judicial powers which enables them from establishing a special court to prosecute persons appearing before it and sentence them even if they have not committed a crime. The sentences might also be applied following a judicial decision by Regular Courts which are competent courts responsible for judicial decision-making.

What makes this law dangerous is that the administrative ruler is not obliged to prove that the person appearing before him or the accused if we can say that, has committed a given act and that the law did not provide controls the administrative governor can adhere to while establishing his convictions based on the suspicion. Not to mention that the judicial authority has no control power over the administrative ruler's decisions and is only subject to administrative justice control.

In addition, this law contravenes Article 24, paragraph 2, of the International Covenant to which Jordan signed. It states that "the accused is presumed innocent until proven guilty", also this law runs contrary with the Principle of Judicial Independence and is considered unconstitutional since there is alternative measures in the Penal Code which are precautionary measures.

\subsection{Prevention of Crimes Law and the encroachment upon the competences of the Judicial Authority.}

It is known that the criminal or penal code, as some legislations call it, is a set of rules that define the acts that are regarded as crimes and the penalties. It also describes the procedures to be followed from the time of commission of the offence until the final judgment is issued and applied. and a procedural formality as mentioned above. It consists of two parts, the first part is substantive i.e. it is a table which illustrates the acts which constitute a crime and the corresponding penalties. The second part is a procedural form as mentioned earlier.

The Crime Prevention Law is those rules that demonstrate the procedures to be followed to prevent the crime from happening. These procedure are called precautionary measure ${ }^{23}$. This law granted administrative rulers broad powers that not only led to duplication, but also led to the abolition of the criminal law in its both formal and substantive parts, giving them the power to impose penalties for acts that are not considered crimes.

These actions are:

${ }^{23}$ Albsoul. Omar (2010), A description of the Prevention of Crimes Law, Dar Al Thaqafa, Amman, p.148.

117 
First: Issuing Summonses and Arrest Warrants as follows:

1. Everyone caught in public or private place in circumstances that may lead the governor to consider that this person was about to commit a crime or assist in committing it. Here we notice a constitutional violation since arrest warrants should only be issued by an order of a judicial authority.

2. Everyone used to robbery, theft, possessing stolen properties, protecting or lodging robbers, assisting in hiding stolen properties or disposing them.

3. Everyone who is free without a warranty might constitute a danger to others ${ }^{24}$.

We note that the Crime Prevention Law granted administrative rulers the power to issue summonses and this authority should only be given to judicial bodies.

The law also granted administrative rulers the power to issue arrest warrants for persons who have been issued a summons and who have not been brought before them within a reasonable period and did not specify what is meant by a reasonable period. The trial must be held within a week from the date of his arrest, then the process of investigations and hearings begins to certify the information provided.

We can therefore say that this law again violated the principle of separation of powers by granting the administrative governor the power to investigate the arrested person.

Second: this law also granted the administrative governor the power to pledge or bail where Article 5, paragraph 2 stipulated that "if, after the investigations, the governor sees that sufficient reasons to bind that person with a pledge, then the governor shall make a decision in this regard provided that this pledge shall not be different from the subject matter mentioned in the process or the warrant of arrest and that their amount and term shall not exceed the ones mentioned in any of them.

If the governor does not consider it necessary to bind that person with a pledge, the governor shall release that person if he is detained.

\section{Third: Administrative Detention}

Article 8 of the Crime Prevention Law states that "If the person in respect of whom a resolution of giving a pledge has failed to provide such pledge in the specified date, then he shall be imprisoned and if he has been already imprisoned, he shall remain imprisoned until he provides the required pledge or if the period mentioned in the resolution of giving the pledge has passed".

Fourth: The Crime Prevention Law not only grant the Governor the powers mentioned above but also the governor may order to put that person under the surveillance of the police for a period not exceeding one year instead of providing a warranty or both procedures might be taken.

Fifth: the Crime Prevention law also granted the governor the power of compulsory residence for the person who has been put under the surveillance of police, and that $\mathrm{He}$ shall reside in an inhabited district, city or village in the Kingdom, and he shall not change his place of residence to any other district, city or village without obtaining a written permission from the police. The governor can banned that person from leaving the district, city or the village where he resides without obtaining a written permission from the police, and that he shall inform the police if he wanted to change his place of residence within the same area.

Sixth: The Crime Prevention Law stated that the person who has been put under the surveillance of police shall appear before the nearest police station whenever instructed by the police officer in charge of the district or the city where he lives. He shall also stay at his residence one hour after the sunset until sunrise. Moreover, The police officers may visit him any time to verify his abidance by this provision.

The legislature also stipulated in this law a penalty of detention/imprisonment for a maximum period of six months or a fine not exceeding fifty JDs or both penalties shall be applicable ${ }^{25}$.

It is clear that the Crime Prevention Law granted the administrative ruler the power to sign precautionary measures which the researcher considers punishments for any person regardless if being a criminal or not since the only criterion is the existence of prior offences and which makes the person go back to crime ${ }^{26}$. This is what makes the Crime Prevention law defective.

\footnotetext{
${ }^{24}$ Prevention of Crimes Article3.

${ }^{25}$ See Aricle. 12,13 of the Prevention of Crimes Law.

${ }^{26}$ Albsoul. Omar (2010), A description of the Prevention of Crimes Law, Dar Al Thaqafa, Amman, p.148.

118
} 
The researcher believes that the Crime Prevention Law is unconstitutional in a way that raises suspicions. He also noticed that this law granted administrative rulers the power to make judicial decisions which are imposed as precautionary measures restricting liberties. The seriousness of this law lies in granting the administrative ruler who doesn't have the qualifications of judges the powers of a judge.

As for the precautionary measurements and granting the power of taking it to administrative governor, it constitutes a serious constitutional violation as these measurements must be taken by the judiciary and that the law should be its source $^{27}$. It should be consistent with the constitutional principles which requires that Criminal offences and penalties shall be determined only by the law, and that they are judicial measure which can only be exercised by a judge ${ }^{28}$.

\section{Conclusion and Recommendations:}

Based on the foregoing, we found that Crime Prevention Law violated the Jordanian Constitutions in many ways such as infringement of competencies, infringement of rights and freedoms and infringement of formal and material supremacy of the constitution.

This law also grants administrative rulers broad powers which enables them to control the executive authority and the judicial authority. Hence, the enforcement of this law causes bad consequences and outcomes at various political, social and economical levels. This law is contrary to the genuine description of law, i.e. Crime Prevention, it also contradicts the Philosophy of Law and the Principles of Sociology.

\section{Recommendations:}

Based on this study, we find that there is a public and official consensus that the Law on the Prevention of Crimes confiscates freedoms and rights and violates the jurisdiction of the judiciary, and the debate is still open about the review of this law which is almost seventy years old.

Some people consider maintaining this law, as the great security role of the administrative rulers in maintaining the security and safety of civil societies needs regulating legislation that reconciles incompatible interests to support the judiciary. Accordingly, the researcher recommends the following:

1) In the face of the great confusion about the unconstitutionality of the crime prevention law, it is necessary to refer this law to the Constitutional Court to decide on this, especially since the Law of the Constitutional Court granted the Council of Ministers and the House of Representatives and the Senate the right to refer laws directly to the constitutional court for conformity with the constitution.

2) The researcher believes that the administrative rulers should be directed to the necessity to not resort to the application of this law, except in cases that require the maintenance of public security and public order in the event of the failure of other procedures to do so.

3) Not to depend entirely on the recommendation of the police to the administrative rulers to apply the Crime Prevention Law.

4) Finding an alternative to the Prevention of Crimes Law that conforms to principles of justice, the Constitution and the Universal Declaration of Human Rights.

5) Expanding the application of the precautionary measures stipulated in Jordan's Penal Code No. 16 of 1960, as these measures may partially alleviate the consequences of the Crime Prevention Act, especially since they are derived from the Penal Code, i.e. it is legitimate. In addition, they are judicial in nature and may only be imposed by a judge. These measures have a personal character, they apply only on a dangerous habitual criminal whose actions can be challenged.

I hope that I have shed the light on this controversial law, an issue that worries the majority of Jordanians.

Acknowledgements: The author would like to thanks Applied Science Private University/ Jordan for its support of this research.

\footnotetext{
${ }^{27}$ Alfadel. Mohammad (1985), General principles in Penal Legislation, Damascus, p.432

${ }^{28}$ Abdelqader Alqahwaji. Ali (1988), Criminology and punishment, Cairo, p.332.

119
} 